\title{
Effect of Madayantika Siddha Taila in Darunaka W.S.R. to Seborrhea Capitis
}

\author{
Dr. Dongre Parshuram ${ }^{1 *}$, Dr. Baghel Prashant ${ }^{2}$, Dr. Salve Nilesh ${ }^{3}$ \\ ${ }^{1}$ Professor and H.O.D, Kayachkitsa Dept. Govt. Ayurved College, Osmanabad, Maharashtra, India. \\ ${ }^{2}$ PG Scholar, Kriya Sharir Dept. Govt. Ayurved College, Osmanabad, Maharashtra, India. \\ ${ }^{3}$ PG Scholar, Agad Tantra Dept. Govt. Ayurved College, Osmanabad, Maharashtra, India.
}

\author{
*Address for correspondence- Dr. Dongre Parshuram, \\ Professor and H.O.D, Kayachkitsa Dept. Govt. Ayurved College, \\ Osmanabad, Maharashtra, India.
}

\begin{abstract}
-
Seborrhea capitis a common chronic scalp condition is marked by itching and flaking of skin. It is termed as Darunaka in Ayurveda. Most of Ayuvedic texts refer this complaint of Darunaka under minor disease (Kshudra Roga). Although the disease rarely causes baldness and hair loss, but the irritation/itching may most certainly be a cause of concern. If white these flakes persist for a long time, the person may experience symptoms of seborrhea, psoriasis and eczema. The treatment part in the modern science is only use of Antidandruff shampoos which has the time limited effect and has recurrence also. Also the shampoo gives the side effects like eyes and skin burning or irritation. But Ayurveda gives a perfect treatment for the disease. AggravatedDosha in Darunaka are Vata and Kapha according to Ayurveda,which causes the dryness and itching of the scalp skin. So the Ayurvedic line of treatment is to generally pacify Kapha and Vata dosha.Madayantika sidhha taila is selected for the study. It contains Tila taila (sesame oil) which is Vata Kaphaghna (pacifying Vata and kapha dosha) and Madayantika which has the property ofKandughna(antipruritic), Vranshodhak(anti-inflammatory or anti-microbial), Vrana ropaka(wound healer), Kushtaghna(antifungal/anti-dermatophytic) etc. This study has revealed the efficacy of Madayantika siddha taila on Darunaka (Seborrhea capitis).
\end{abstract}

KEY WORDS- Darunaka, Seborrhea capitis, Madayantika siddha taila, Seborrheic dermatitis

\section{INTRODUCTION-}

According to the science the hairs comes under vestigial part of the body, but when it comes to the cosmetic grounds it is one of the important subject. Hair fall, dandruff or greying of the hair makes people concerned. Healthy hairs are necessary for self-confidence which can boost the career. The quality and texture of the hairs differ from person to person.Unhygienic conditions and excessive use of cosmetic products, pollution and many more factors can cause hair problems. Likewise Seborrhea capitis (Darunaka) is one of the major hair problems.Darunaka that is Seborrhea capitis as per Ayurvedic term should be explored by doing some research work. To eradicate this problem, Ayurvedic therapy seems to be one of the most important remedy.

In Granthas we get comparatively less information about Darunaka. The disease is considered Kshudrarogaas per Sushrut samhita ${ }^{(1)}$ and Shiroroga as per Vagbhatsamhita ${ }^{(2)}$. It causes dryness and itching in Keshabhumi (scalp). The dominant Doshas are Vata and Kapha ${ }^{(3)}$, they causes the severe irritation and itching of the scalp skin. The main Sthana (location) of disease is the Keshabhumi (scalp). According to the modern science the symptom of Darunaka is represented under Seborrhea capitis. Continuous itching of scalp causes scaly layers and its shading on the back and neck causing seborrheic dermatitis. The abnormal keratinization that is excessive formation of the keratin in the hair roots and epidermal cells can cause Darunaka (Seborrhea capitis). 


\section{Composition and properties of Madayantika sidhha taila}

It contains-

Madayantika(Lawsonia inermis)

Tila taila (Sessamum indicum)

Lawsonia inermis is a scientific name of a tall shrub plant commonly known as Henna or Mehndi ${ }^{(4)}$ Sanskrit name is Madayantika and it contains ${ }^{(5)}$ Lawsone (2- hydroxynaphthoquinone), mucilage, mannite, galic acid and tannic acid, saponins, cardiac glycosides, flavonoids, terpenoids. It is known to be used as cosmetic agent for dyeing hair, nails and skin. ${ }^{(6)}$

\section{Properties in details of the Madayantika (Lawsonia inermis) ${ }^{(7)}$}

\section{Anti-dermatophytic properties-}

Ethanol, ethyl acetate, extracts of Lawsonia inermis shows anti-dermatophytic activity. The tests were taken of 5 different strains of Tinia rubrum and Tinia mentagrophytes. Over all studies shows anti-dermatophytic mechanism.

\section{Antifungal activity-}

The leaves ethanol, methanol and aqueous extracts which have shown the defensive mechanism against the spore germination of Drechslera onzyea. The isolated form of the leaves shows significant antifungal effect. The extract showed fungitoxic spectrum when tested against several fungi. The effect also remains unaltered in high temperature and also autoclaving along with long storage.

\section{Antioxidant activity-}

The $80 \%$ ethanol extract from the Madayantika tail shows modular effect on drug metabolizing phase 1 and phase 2 enzymes anti-oxidant enzymes in the liver of Swiss albino mice. With reference to anti-oxidant enzymes the investigated doses were effective in increasing the hepatic glutathione reductase, superoxide dismutase and catalase activities significantly at both the dose levels. Chloroform extract from leaves of Lawsonia inermis had shown significant antioxidant activity.

\section{Anti-bacterial activity-}

The Ethanol extract from the plant Lawsonia inermis, can be used to treat infectious disease. It has antibacterial effect on both gram positive and gram negative organism. Also the biochemical tests proved that ethyacetate extract from Lawsonia inermis has most active effect against the bacteria.

\section{Properties of Tila taila (Sesame oil)-}

The physiochemical composition and various analyses show such factors in the Tila taila i.e. sesame seed oil which appears to be very useful in Darunaka. The composition of sesame seeds- $50-60 \%$ high quality of oil which is rich in polyunsaturated fatty acid (PUFA) and natural antioxidants, sesamin, sisamolin and tocopherol homologues. ${ }^{(8)}$

Sesame seed is high in protein, vitamin B1, dietary fibres as well as an excellent source of phosphorous, iron, magnesium, calcium, copper, zinc.We have observed how these properties act on Darunaka. The calcium is $351 \mathrm{mg}$ which is large in quantity, it has antifungal activity. Chlorosesamone which is a pigment possess this antifungal activity. This can be derived from the roots of tree. The oil also shows antibacterial activity, so it is used against Pitta utpatti (aggravating Pitta) in Darunaka. This activity is also useful in many other diseases.So, Tila taila acquires an important place in the Ayurveda therapy. Beside that the dry flowers of sesame are also used in alopecia. The copper content is $74 \%$ which can again reduce swelling and irritation.

\section{Antifungal activity-}

It shows antifungal activity or effective against clodosporium fulvano of chlorosesamone and hydroxyl sesame. ${ }^{(9)}$

\section{Astringent activity-}

The leaves and seeds show this effect so when taken internally it can prevent hair loss, alopecia, greying of hairs, and many other diseases. Sesame seed and oil promote wound healing. ${ }^{(10)}$ 
Dr. Dongre Parshuram ${ }^{1 *}$, International Journal of Ayurvedic \& Herbal Medicine 7(4) July.-Aug.2017 (2693-2699)

The stringent activity is due to some alcohols in the seeds which remove grease from the pores of the scalp skin. And tighten the skin so no pollution can cause harm to the scalp skin eventually hair loss and dandruff can be treated. Zinc is another important part which is the wound healer i.e. Vrana ropaka and can treat Pitika (furuncle) in Darunaka. It can also be used in many other skin disease, besides this it action as a soother for the scalp skin. So the symptom in the Darunaka like itching, rashes can be cured and patient does not get annoyed. It also acts as anti-inflammatory so as the blisters on the scalp can be treated. In this way various properties in the Tila taila proves to be very useful in the Darunaka. So Madayantika and Tila taila are very useful in Darunaka vyadhi.

Properties of Madayantika sidhha taila-
1. Anti-dermatophytic
2. Antifungal
3. Antioxidant
4. Antibacterial
5. Antimicrobial
6. Antiviral

\section{METHODOLOGY}

1. For this research project patient were selected at random and irrespective of the age, sex, socio economic condition.

2. As the study was clinical the tail was tested on patient suffering especially from Darunaka.

3. We prepared Madayantika siddha taila according to Bhaishajya Ratnavali,First Taila Murchhana procedure was done. In this procedure we have taken 64 parts of water along with 16 part of Tila taila and 4 part of Madayantika kalka. And prepared Madayantika siddha taila. ${ }^{(1)}$

4. The duration of treatment was 1 month

5. Each patient was asked to apply Madayantika siddha taila on the Keshbhumi/scalp on hair every night for 30 days

6. The records of clinical data collected after 1 month was taken for observation, discussion and conclusion

7. It was decided to take 50 patients specially suffering from Darunaka.

8. The age, sex, occupation and Prakruti of each patient was recorded and status of relief of each patient was also recorded.

9. No. of tables were made on the basis of sex, age, occupation, Prakruti, and state of relief for final assessment of the efficiency.

\section{INCLUSIVE CRITERIA}

1. Ambulatory patient of both sexes

2. Clinical diagnosis of Darunaka isbased on clinical textbook criteria i.e. patient at the time of enrolment in this study have mild to severe Darunaka.

\section{EXCLUSIVE CRITERIA}

1. Patients with severe dermatitis involving face, neck and extremities.

2. Psoriasis, allergic contact dermatitis.

\section{OBSERVATION}

Observation analysed as follow-

Table no. 1 - Sex wise analysis of 50 patients

\begin{tabular}{|c|c|c|c|}
\hline Sr. No. & Sex group & No. of Patients & Percentage \\
\hline 1. & Male & 16 & $32 \%$ \\
\hline 2. & Female & 34 & $68 \%$ \\
\hline & Total & 50 & $100 \%$ \\
\hline
\end{tabular}


Dr. Dongre Parshuram ${ }^{1 *}$, International Journal of Ayurvedic \& Herbal Medicine 7(4) July.-Aug.2017 (2693-2699)

Table no. - 2Age wise analysis

\begin{tabular}{|c|c|c|c|}
\hline Sr. No. & Age group (Year) & No. of Patients & Percentage \\
\hline 1. & $11-15$ & 03 & $06 \%$ \\
\hline 2. & $16-20$ & 09 & $18 \%$ \\
\hline 3. & $21-25$ & 27 & $54 \%$ \\
\hline 4. & $26-30$ & 07 & $14 \%$ \\
\hline 5. & $31-35$ & 03 & $06 \%$ \\
\hline 6. & $36-40$ & 01 & $02 \%$ \\
\hline & Total & 50 & $100 \%$ \\
\hline
\end{tabular}

Table no. 3 - Education wise analysis

\begin{tabular}{|c|c|c|c|}
\hline Sr. No. & Status & No. of Patients & Percentage \\
\hline 1. & Educated & 50 & $100 \%$ \\
\hline 2. & Uneducated & 00 & $00 \%$ \\
\hline & Total & 50 & $100 \%$ \\
\hline
\end{tabular}

Table no. 4 - Economic wise analysis

\begin{tabular}{|c|c|c|c|}
\hline Sr. No. & Economic state & No. of Patients & Percentage \\
\hline 1. & Higher class & 01 & $02 \%$ \\
\hline 2. & Middle class & 38 & $76 \%$ \\
\hline 3. & Lower class & 11 & $22 \%$ \\
\hline & Total & 50 & $100 \%$ \\
\hline
\end{tabular}

Table no. 5 - Occupation wise analysis

\begin{tabular}{|c|c|c|c|}
\hline Sr. No. & Type of occupation & No. of Patients & Percentage \\
\hline 1. & Students & 26 & $52 \%$ \\
\hline 2. & Home duties & 17 & $34 \%$ \\
\hline 3. & Service & 04 & $08 \%$ \\
\hline 4. & Business & 02 & $04 \%$ \\
\hline 5. & Teacher & 01 & $02 \%$ \\
\hline & Total & 50 & $100 \%$ \\
\hline
\end{tabular}

Table no. 6 - Koshtha wise analysis

\begin{tabular}{|c|c|c|c|}
\hline Sr. No. & Koshtha Prakar & No. of Patients & Percentage \\
\hline 1. & Krura & 27 & $54 \%$ \\
\hline 2. & Madhyam & 15 & $30 \%$ \\
\hline 3. & Mrudu & 08 & $16 \%$ \\
\hline & Total & 50 & $100 \%$ \\
\hline
\end{tabular}

Table no. 7 - Prakrutiwise analysis

\begin{tabular}{|c|c|c|c|}
\hline Sr. No. & Prakruti & No. of Patients & Percentage \\
\hline 1. & Vatapradhana & 02 & $04 \%$ \\
\hline 2. & Pittapradhana & 01 & $02 \%$ \\
\hline 3. & KaphaPradhana & 02 & $04 \%$ \\
\hline 4. & Vatapittatmaka & 11 & $22 \%$ \\
\hline 5. & Vatakaphatmaka & 21 & $42 \%$ \\
\hline 6. & Kaphapittatmaka & 13 & $26 \%$ \\
\hline 7. & Tridoshatmaka & 00 & $00 \%$ \\
\hline & Total & 50 & $100 \%$ \\
\hline
\end{tabular}


Dr. Dongre Parshuram ${ }^{1 *}$, International Journal of Ayurvedic \& Herbal Medicine 7(4) July.-Aug.2017 (2693-2699)

Table no. 8 - Itching symptom wise analysis

\begin{tabular}{|c|c|c|c|}
\hline Sr. No. & Gradation of itching & No. of Patients & Percentage \\
\hline 1. & Mild & 10 & $20 \%$ \\
\hline 2. & Moderate & 30 & $60 \%$ \\
\hline 3. & Severe & 10 & $20 \%$ \\
\hline & Total & 50 & $100 \%$ \\
\hline
\end{tabular}

Table no. 9 - Shading of scaly layer wise analysis

\begin{tabular}{|c|c|c|c|}
\hline Sr. No. & Gradation of type of shading & No. of Patients & Percentage \\
\hline 1. & Mild & 15 & $30 \%$ \\
\hline 2. & Moderate & 25 & $50 \%$ \\
\hline 3. & Severe & 10 & $20 \%$ \\
\hline & Total & 50 & $100 \%$ \\
\hline
\end{tabular}

Table no. 10 - Relief wise analysis of itching

\begin{tabular}{|c|c|c|c|}
\hline Sr. No. & Gradation of itching & No. of Patients & Percentage \\
\hline 1. & Fair & 04 & $08 \%$ \\
\hline 2. & Good & 40 & $80 \%$ \\
\hline 3. & Excellent & 06 & $12 \%$ \\
\hline & Total & 50 & $100 \%$ \\
\hline
\end{tabular}

Table no. 11 - Relief wise analysis of Shading of scaly layer

\begin{tabular}{|c|c|c|c|}
\hline Sr. No. & Gradation of itching & No. of Patients & Percentage \\
\hline 1. & Fair & 01 & $02 \%$ \\
\hline 2. & Good & 45 & $90 \%$ \\
\hline 3. & Excellent & 04 & $08 \%$ \\
\hline & Total & 50 & $100 \%$ \\
\hline
\end{tabular}

Table no. 12 - Relief wise analysis of Darunaka

\begin{tabular}{|c|c|c|c|}
\hline Sr. No. & Gradation & No. of Patients & Percentage \\
\hline 1. & Fair & 03 & $06 \%$ \\
\hline 2. & Good & 42 & $84 \%$ \\
\hline 3. & Excellent & 05 & $10 \%$ \\
\hline & Total & 50 & $100 \%$ \\
\hline
\end{tabular}

\section{RESULT AND DISCUSSION}

All the details study of 50 patients according to the various aspects provides the clear idea of the result of the Madayantika siddha Taila. After doing the analysis of 50 patients various result were seen which were positive. The analysis was done on different ground. Those are -

1. Sex wise analysis -When 50 patients were observed, male patients were 16 i.e. $32 \%$ and female patients were 34 i.e. $68 \%$

2. Age wise analysis - The patients of different age group were observed. The patient from 11-15 age were 3 i.e. $6 \%, 16-20$ were 9 patients i.e. $18 \%$, patients from $21-25$ age patients were 27 i.e. $54 \%$, 26-30 year old patients were 7 i.e. $14 \%$, from $31-35$ age patients were 3 i.e. $6 \%$ and finally the patient from age 36-40 was 1 i.e. $2 \%$. The study of the patients according to this age group was done.

3. Education wise - There were only two gradations, first the educated patients were 50 i.e. $100 \%$ and no uneducated patient was found. 
Dr. Dongre Parshuram ${ }^{1 *}$, International Journal of Ayurvedic \& Herbal Medicine 7(4) July.-Aug.2017 (2693-2699)

4. Koshtha wise-According to Ayurveda Koshtha is one of the important factor. So patient according to Koshtha were also studied. The patients of Krurakoshtha were 50 i.e. 30\% Madhyam Koshtha were 27 Patients i.e. 54\% and the patients with Mrudu Koshtha were 8 i.e. $16 \%$.

5. Prakrutiwiseanalysis- Again the Prakruti Abhyas is also necessary for the gradation. The patients were with-

Vatapradhana Prakruti - 2 i.e. $4 \%$

Pittapradhan Prakruti- 1 i.e. $2 \%$

Kaphapradhan Prakruti- 2 i.e. $4 \%$

Vatapittatmaka Prakruti- 11 i.e. $22 \%$

Vatakaphatmaka Prakruti- 21 i.e. $42 \%$

Kaphapittatmaka Prakruti- 13 i.e. $26 \%$

Tridoshatmaka Prakruti patients were nil.

6. Economic wise - Economic status can also give an important place in occurrence and relief of the disease so it was also studied. The high class patients were 1 i.e. $2 \%$ and middle class patients were 38 i.e. $76 \%$ and lower class patients were 11 i.e. $22 \%$.

7. Occupation wise analysis - Occupation shows a deep impact on the person. So it should be considered. The students were 26 i.e. $52 \%$, patients under service were 4 i.e. $8 \%$, patients engaged in various business were 2 i.e. $4 \%$, teacher was 1 i.e. $2 \%$ and patient enrolled in the home duties were 17 i.e. $34 \%$.

8. Symptoms itching wise analysis- The second measure symptoms of Darunaka is itching, so according to this point observation was done carefully. Mild itching was seen in 10 patients i.e. $20 \%$, and 30 patients i.e. $60 \%$ patients were seen with moderate itching and 10 patients i.e. $20 \%$ were seen with severe itching.

9. Symptoms Shading of scaly layer wise analysis-The second measure symptom of Seborrhea capitis is shading of scaly layer, mild shading of scaly layer was seen in 15 patients i.e. $30 \%$ moderate shading was seen in 25 patients i.e. $50 \%$ and severe shading of scaly layer was seen in 10 patients i.e. $20 \%$

10. Relief wise analysis of itching symptoms- In relief wise analysis of itching symptom, 4 patients i.e. $8 \%$ have fair relief, good relief in 40 patients i.e. $80 \%$. And 6 patients i.e. $12 \%$ of patients have excellent relief.

11. Reliefwise analysis of Darunaka (Seborrhic Capitalia)- After one month of Madayantika sidhha tail application on scalp skin, there is fair relief in 3 patients i.e. $6 \%$. Good relief in 42 patient's i.e. $84 \%$. and excellent relief seen in 5 patients i.e. $10 \%$

\section{CONCLUSION -}

Finally we can firmly conclude that chemical properties of the Madayantika herbi.e. anti-fungal, antidermatophytic, anti-oxidant, anti-bacterial, anti-viral are useful to get rid of fungal, bacterial, viral, parasitic infection of scalp which can cause dandruff are cured by Madayantika herb. Similarly Tila taila which is again very important ingredient of Madayantika siddha taila also actspromptly on dandruff. It is having antiinflammatory, anti-fungal, anti-oxidant, astringent properties.

So the dandruff can be cured. Also it has wound healing property which is helpful in dandruff. After acknowledging the properties and action of Madayantika siddha tailaaccording to Ayurvedic and modern science, it is seen that it has good effect on seborrhea capitis or Seborrheic dermatitis. But recurrence can occur. The recurrence only occurs if the patient comes in contact with Hetu (causes). Regular use of Madayantika siddha taila proves to be perfect remedy for such patients.

\section{REFFERENCES-}

1. Dr. Anantram Sharma. Sushrut Samhita, Vol. 1, Varanasi; Chaukhamba Subharati Prakashan; 2012. (Nidanasthana 13/3) Page no. 554 
Dr. Dongre Parshuram ${ }^{1 *}$, International Journal of Ayurvedic \& Herbal Medicine 7(4) July.-Aug.2017 (2693-2699)

2. Kaviraj Atridev Gupta. Ashtanga Hridayam, Varanasi; Chaukhamba Prakashan; 2011. (Uttarasthana 23/23) Page no. 728

3. Dr. Anantram Sharma. Sushrut Samhita, Vol. 1, Varanasi; Chaukhamba Subharati Prakashan; 2012. (Nidanasthana 13 /36) Page no. 558

4. MuhammadHS, Muhammad S. The use of lowsonia inermis linn(henna) in the management of wound infections. Afri J biotechnol. 2005; 4:934.

5. Al Rubiay KK et al. Antimicrobial activity of henna extract. Oman Med J. 2008; 200(23):253-256

6. Hanna $\mathrm{R}$ et al. Molecular structure and infra-red spectra of 2-hydroxy-1,4-naphthoquinone; Experimental matrix isolation and theoretical Hatree-Fock and post Hatree-Fock study. Spec Act. 1998;1998(54): 1091-1103

7. Gangadeep Chaudhary et al. Lowsonia inermis : A phytopharmacological study. International Journal of pharma and drug research 2010; 2(2): 91-98

8. Brar G, Ahuja KL. Sesame: Its culture genetics, breeding and biochemistry. Annu Rev Plant sci. 1979; $1: 245-313$

9. Dhamija Isha and Parle Milind. International Research Journal of Pharmacy 2012, 3(11)

10. Kiran R, Asad M. Wound healing activity of Sesamum indicum L Seed and oil in rat. Indian J ExpBiol. 2008; 46(11); 777-82

11. Acharya Siddhinanadan Mishra. Bhaishajya Kalpana Vigyana. Varanasi; Chaukhamba Prakashan; Chapter no. 8 Page no. 222-225 